\title{
INNSAN HAKLARI HUKUKUNDA İNSAN ONURUNUN YERİ VE ROLÜ
}

THE PLACE AND ROLE OF HUMAN DIGNITY IN HUMAN RIGHTS LAW

Hakemli Makale

Elif ÇELIK*

\section{IÇİNDEKILER}

GİRIŞ.

.283

I. INSAN ONURUNA KISA BİR KAVRAMSAL BAKIŞ .....................................285

II. ULUSLARARASI İNSAN HAKLARI HUKUKUNDA İNSAN ONURU........................291

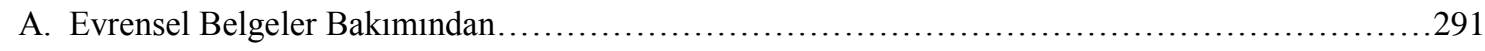

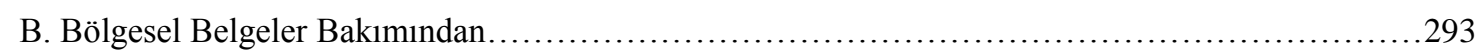

III. BELGELER IŞIĞINDA İNSAN ONURUNUN EVRENSEL VE AVRUPA DÜZEYINDEKİ

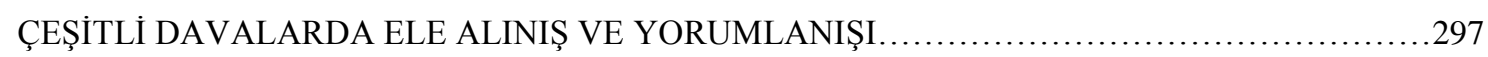

A. Evrensel İnsan Hakları Yargılamaları Bakımından...............................................298

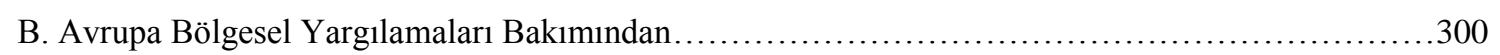

C. Avrupa Birliği Bölgesel İnsan Hakları Yargılamaları Bakımından.................................303

IV. İNSAN ONURU KAVRAMININ ARDINDA BIRAKTIĞI SORULAR VE BİR

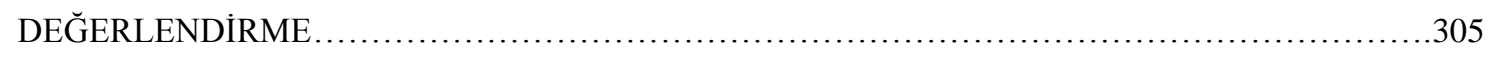

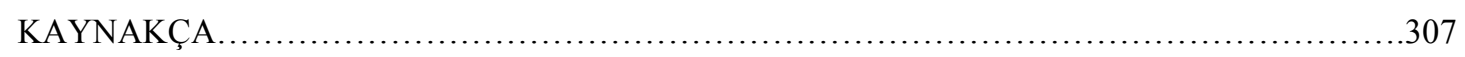

DOI: $10.32957 /$ hacettepehdf.635313

Makalenin Geliş Tarihi: 10.04.2019

Makalenin Kabul Tarihi: 18.07.2019

* Dr. Öğr. Üyesi, İnönü Üniversitesi Hukuk Fakültesi, İnsan Hakları Hukuku Anabilim Dal1.

E-posta: elif.celik@inonu.edu.tr

Bu makale kısmen yazarın doktora tezinin bir bölümünden türetilmiştir.

ORCID: 0000-0003-4380-1767 


\title{
ÖZ
}

İnsan Hakları Evrensel Bildirgesinin başlangıç satırlarında yer alan kavramlardan bazılarının altının, son yıllarda, gerek literatürde gerekse insan hakları mücadele alanlarında özellikle çizilir olduğu görülmektedir. Bunlardan biri de insan onuru kavramıdır. Bu çalışma, kavram etrafından dönen teorik tartışmaların da ışı̆̆ında, kavram ve insan hakları arasındaki ilişkiyi ele almayı amaçlamaktadır. Bu doğrultuda, kavramın uluslararası insan hakları hukukuna konu olan evrensel ve bölgesel belgelerde yer alış süreci ve biçimi ele alınacaktır. Bunu takiben kavramın özellikle insan hakları yargılamaları bakımından etkinliğine ilişkin literatürde yer bulan sorgulama, eleştiri ve değerlendirmelere yer verilecek ve söz konusu tartışmalar evrensel ve Avrupa bölgesel insan hakları yargılamalarından kimi örneklerle somutlaştırılmaya çalışılacaktır.

Anahtar Kelimeler: İnsan onuru, insan hakları, uluslararası insan hakları hukuku

\begin{abstract}
It appears that some of the notions that find place in the preamble of the Universal Declaration of Human Rights are being particularly underlined, in recent years, both in human rights movement and literature. One of them is the concept human dignity. This study, within the light of some theoretical arguments, aims to tackle the relation between the concept and human rights. In this respect, the development and the position of the concept regional and international human rights documents will be examined. Following to this; some questionings, critics and evaluations concerning the efficiency of the concept in terms of human rights judiciary will be covered and by referring to some human rights cases from international and European regional aspects they will try to be concretized.
\end{abstract}

Keywords: Human dignity, human rights, international human rights law

\section{GíRiş}

İnsan onuru ${ }^{1}$ kavramına, politik ve hak temelli söylem ve mücadelelerde artan bir sıklıkla atıf yapılıyor olması, ilk bakışta problemli gelmeyebilir. Nitekim, gündelik dildeki rastlantısal kullanımları bir yana, kavramın, bilhassa son yıllarda

1 İnsan hakları metinleri 1şı̆̆ında, Türkçe'de kimi zaman ve hatta sıklıkla haysiyet olarak da kullanılabilen bu kavramı, insan onuru sözcüğü ile karşılamayı tercih ettim. Bizzat haysiyet kavramından yola çıkarak kavramın etimolojisini ve semantiğini konu edinen bir tartışmayı ülkemizde yıllar evvel Orhan Koçak kaleme almış. KOÇAK, Orhan, "Haysiyet Kavramı Çerçevesinde” Defter Dergisi, Y1l: 2000, Say1: 40. 
evrensel insan haklarına ilişkin teorik ve pratik dilde neredeyse bir boşluk doldurucu görevi görme yolunda ilerlediği gözlemlenebilmektedir. Öte yandan kavrama yapılan bir göndermenin ya da salt bir telaffuzun, bir hak arayışının sınırlarını nasıl ve neden değiştirebileceği/değiştirmesi gerektiği şüphesiz hukuk ve bu hukuka konu olan insan arasındaki ilişkiden bağımsız düşünülemeyecektir. Üstelik kavramın, fazla da irdelenmeyi gerektirmeyen, kendinden menkul bir değere/güce sahip olduğu düşünülüyorsa bu 'gücün' -daha nadir de olsa- aynı zamanda insan hakları fikrinin kendisiyle çelişen olası yorumlara da açık olabileceği gözden kaçabilmektedir. O hâlde kavramı konu edinen bir incelemede problem edinilmesi gereken noktalardan biri kavramı açığa çıkarmaya ilişkin olacaktır. Böyle bir açığa çıkarma çabasıysa felsefi, teolojik, sosyo-politik ve kültürel ögelerden beslenebilecek türdedir ve bu çalışmanın sınırlarını aşmaktadır. Hukuk dahilinde belki daha pragmatik bir yaklaşım, insan haklarını gerçekleşir kılmak adına var olan yazılı evrensel kaynaklar ve yargısal pratiklerde kavramın nasıl ele alındığı ve nasıl iş gördüğü/görmesi gerektiği sorusunu sormak olabilir. Bu bakımdan bu çalışma insan onuru kavramını, evrensel ve bölgesel insan hakları hukukunun kaynak ve çıktıları bakımından ele almakla sınırlı olacaktır. Şüphesiz insan onurunun insan hakları yargısı bakımından oynadığı role ilişkin ilk durak, kavramın ülkelerin anayasalarında ne şekilde yer bulduğu ve ulusal mahkemelerce nasıl yorumlandığı sorusudur. Ancak böylesine ayrıntılı ve farklılıklar arz eden bir konu bu çalışma dâhilinde problem edinilmeyecektir. Bu çalışma ise, sırasıyla uluslararası ve bölgesel insan hakları belgelerinde insan onurunun düzenlenişini ele alırken aynı zamanda söz konusu belgelerin sağladığı koruma mekanizmalarında kavramın nasıl konu edindiğine dair örneklere yer vererek, kavram etrafındaki tartışma ve olası açmazları ele almakla sınırlı kalacaktır. Bölgesel yargı mekanizmaları açısından ise, kavramın kıta açısından oynadığı önemden de yola çıkarak, Avrupa bölgesel mekanizmaları ile sınırlı kalınacaktır. 


\section{I. İNSAN ONURUNA KISA BİR KAVRAMSAL BAKIȘ}

$\mathrm{Bu}$ çalışma çerçevesinde, her ne kadar insan onuru kavramı ve hukuk ilişkisi ele alınacak olsa da özet düzeyde ve yalnızca belirli yönleriyle bir kavramsal irdeleme yapmaksızın konuya geçmek mümkün görünmemektedir. Zira kavramı hukukla olan ilişkisinde ele alırken ve pratikte gerçekleşir kılarken, pozisyon alacağımız yeri gözetmek ve kavrama dayanarak işaret edilebilecek kimi sorunlu alanları fark edebilmek, kavramdan ne anladığımızdan bağımsız olamayacaktır.

O hâlde bu kısa değerlendirmeye belki insan onuru kavramını anlam ve içerik bakımından insan şerefi ya da namusu gibi sözcüklerden ayıran şeyin ne olduğu sorusuyla başlanabilir. ${ }^{2}$ Buna ilişkin akla gelebilecek ilk cevapsa bizi insan onurunun kaynağ1 sorusuna götürecektir. Örneğin; şeref, namus, haysiyet gibi kavramlar kültürel ve toplumsal bağlamlarında şahısları ilgilendiren, şahıslara ya da topluluklara atfedilen yakıştırmalar olurken; insan onuruyla imlenen şey, en azından insan hakları hukuku bakımından, insanlık ailesinin mensubu olarak varlıkta sahip olunan özellikli ve türcülük eleştirilerini göze almak gerektiğini de not düşerek- ayrıcalıklı bir yeri işaret etmektedir. ${ }^{3}$ Fark edilebileceği gibi, bu noktada bir başka ayrım yatmaktadır. $O$ da: kişilerin bizzat yapıp ettikleriyle, toplumsal, kültürel ve tarihsel odaklı, kazanıp kaybedebilecekleri bir haysiyet/şeref anlayışıyla; zaten doğuştan sahip oldukları, içkin bir insan onuru arasındaki ayrımdır. ${ }^{4}$ Bir başka deyişle sosyal bir kavram olarak insan onuru ile ahlaki bir kavram olarak insan onuru arasındaki farktır. İşte, bu her tek insan

2 Söz konusu farka ilişkin bir tartışma İoanna Kuçuradi tarafından ele alınmıştır. KUÇURADİ, İoanna, İnsan Hakları Kavramı ve Sorunları, Türkiye Felsefe Kurumu, 2007, s. 73-74.

$3 \mathrm{Bu}$ anlamda Taylor, şeref ve insan onuru arasındaki ayrıma değinirken, şeref (honor) olarak adlandırılabilecek konum ya da statünün dayanağı olan sosyal hiyerarşilerin çöküşünü ele alır. Bu açıdan şeref, eski kullanımına paralel, herkesin bu mertebeye sahip olmaması dolayısıyla esasen sosyal eşitsizlikleri de doğal olarak bünyesinde barındıran bir tanımdır. Oysa bugün insan onuru olarak kullanılan kavram bilhassa eşitlikçi bir vurgu içermektedir. TAYLOR, Charles, Multiculturalism Examining the Politics of Recognition, 1994, s. 26-27.

4 Öte yandan insan onurunu salt içkin bir unsur olarak ele almak belki yalnızca insan haklarına bir felsefi temel aramak bakımından etkin olsa da onur kavramının toplumsal, kültürel önemi bilhassa sosyal ekonomik hakların ele alınması bakımından; aynı zamanda tanınma, saygı görme ve eşitlik arasındaki ilişki perspektiflerinden azımsanmayacak düzeydedir. $\mathrm{Bu}$ anlamda insan onuruna uygun muamele, çalışma ve yaşam standartları gibi kavramlar şüphesiz toplumsal bir statü olarak onura gönderme yapmaktadır. 
kişisinin sadece insan olmaktan kaynaklanan değerliliği, daha doğru bir ifadeyle değerli olduğu savı, uluslararası hukukta insanın haklarını konu edinen belgelerin de dayandığı noktadır. İnsanın söz konusu değerliliğine ilişkin bu savsa zaman içinde teolojik, felsefi, biyolojik, sosyo-ekonomik gerekçelere dayandırabileceği gibi, yine bu ve benzer noktalardan yöneltilebilecek bir meydan okumanın hedefi haline getirebilir. Bu noktada söz konusu değerliliğin ne üzerine inşa edileceğinin titizlikle düşünülmesi gerekir. Bu bakımdan insan onuru kavramının liberal hukuk düzenleri tarafından bu denli benimsenmesinin, kavramın bilhassa tarihselliğini gözeten yazarlar tarafından mesafeyle karşılandığını belirtmekte fayda vardır. ${ }^{5}$ Öte yandan bu çalışma dâhilinde, kavramın hali hazırda pozitif insan hakları hukukunda bir 'kabul'ü yansıtıyor olması ${ }^{6}$ üzerinden ilerlenmektedir. Akla gelebileceği üzere bu türden bir kabule, en çok da, insan haklarına evrensel bir temel arayışı ihtiyacı yön vermektedir. $\mathrm{Bu}$ anlamda literatürde kavrama büyük çoğunlukla insan haklarının 'nedeni' sorusuna ikna edici ve evrensel bir argüman olarak başvurulduğu görülmektedir. ${ }^{7}$ Öyle ki bugün insan haklarına teorik bağlamda yöneltilen eleştirilerin başında yer alan evrensellik argümanı, temeline farklılıkları değil ortaklıkları alan bir iddiaya dayanmak durumundadır ve hatta kimi yazarların iddialarına göre evrensellik iddiasında olan bir argüman olan insan onuru, her daim metafizik bir argüman olmaya mahkumdur. ${ }^{8}$ Evrensel Bildirgeyi kaleme alan isimlerden biri olan Maritain'ın dile getirdiği gibi: her ne kadar insan hakları konusunda bir uzlaşıya varılmış olsa da bu uzlaşı kimse tarafindan 'neden' sorusunun yöneltilmemesi şartına bağlıdır. ${ }^{9} \mathrm{Bu}$ anlamda insan onuru kavramının burada

5 DOUZINAS, Costas, Human Rights and Empire: The Political Philosophy of Cosmopolitanism, Abingdon,Routledge-Cavendish, 2007, s. 8.

6 Örneğin Barrosso, insan onurunun bilhassa Batı'da insan hakları yargısı bakımından üzerinde konsensüs olan kavramlardan biri haline geldiği ifadesine başvurur. BARROSSO, Roberto, "Here, There, Everywhere: Human Dignity in Contemporary Law and in The Transnational Discourse" Int'l \& Comp. L. Rev, Y11: 2012, Cilt: 35, Say1: 2, s. 332.

7 Bu kabule ilişkin verilebilecek isimler çokça olmakla birlikte literatürde sıklıkla Donnelly’e referans verildiği gözlemlenmektedir. Bunlardan yalnızca biri için bkz: DONELLY, Jack, "Human Rights and Human Dignity: An Analytic Critique of Non-Western Conceptions of Human Rights", The American Political Science Review, Cilt: 76, Sayı: 2.

8 İnsan haklarının temelinde olan insan onuruna ilişkin dini bir temellendirmenin iş göreceğinden yana olan Perry bu iddianın sahibidir. PERRY, Michael, Toward a Theory of Human Rights, Cambridge University Press, 2007, s. 8-12.

9 MARITAIN, Jacques, UNESCO İnsan Hakları Yorum ve Uygulama belgesinde yer alan önsözü 
pragmatik bir çözüm önerisi, bir çeşit tartışma bertaraf edici olarak kullanılmış olduğu tespiti de yine bazı yazarlar tarafından dile getirilmiş bir argümandır. ${ }^{10}$

İnsan onuru sözcüğünün, uluslararası insan hakları metinlerine egemen dil olan İngilizcedeki karşılığı dignity kelimesi olup, sözcük kaynağını Latince olan dignitas’tan almaktadır. Dignitas'ın tarih içinde büründüğü kullanım alanlarının ve kendisine dignitas atfedilen kişilerin sınırlılığının yarattığı tartışma ${ }^{11}$ göz önüne alındığında ise şu sonuç ortaya çıkar: bugün insan onuru olarak kullandığımız ve insanlık ailesinin tüm mensuplarını içine aldığı iddiasında olan bu kavramın, herkesin eşit haklara sahip olduğu yönündeki bir iddiayı desteklemek için kullanımı esasen oldukça yakın bir tarihte başlamaktadır. Daha ileri giderek, bu kullanımın ortaya çıkmasında, insan onuru kavramının yaygınlaşmasında, bizzat insan hakları düşüncesinin ve metinlerinin rol oynadığı söylenebilir. Bu, şüphesiz kavramın daha önceleri kullanılmadığı anlamına gelmez. Bu anlamda, kavramı tarihsel bağlamından ve teolojik çağrışımlardan bağımsız, modern anlamda ele alan bir isim olan Kant, söz konusu değeri (onuru) insanın özgür ve ahlâki tercihler yapabilmesi nedenine bağlamıştır. ${ }^{12}$ Ancak elimizdeki en seküler gerekçe gibi görünen rasyonalite odaklı bu yaklaşım, günümüz insan hakları anlayışı ve arayışına temel teşkil edebilecek bir onur içeriklendirmesi olarak ele alınmak bakımından kimi düşünürlere göre yetersiz ve dışlayıcıdır. ${ }^{13}$ Dolayısıyla Evrensel Bildirge ve onu takip eden belgelerde özellikli olan nokta, bu kullanımın, her insan onurlu bir varlık olduğu için haklar ve özgürlükler bakımından eşit olduğu yönündeki bir vurgudur. O hâlde denilebilir ki, insan onuru kavramının, her tek insanın eşit haklara sahip olmasının önkoşulu yahut gerekçesi olarak kullanılması ve dahası bu biçimiyle

10 SCHUltzINER, Doron, "Human Dignity: Functions and Meanings", Perspectives on Human Dignity içinde, 2007, s. 78.

11 Köleler, kadınlar, toprak sahibi olmayan erkekler akla gelebilen ilk örneklerdir. Bu anlamda dignitas, kimi yazarların not ettiği gibi, antik dönemde hiyerarşik bir kullanımı yansıtırken ancak modern dönemde demokratik ve eşitlikçi bir görünüm kazanmıştır.

12 KANT, Immanuel, Ahlâk Metafiziğinin Temellendirilmesi (çev. İ. Kuçuradi), Türkiye Felsefe Kurumu Yayınları, 2009, s. 53.

$13 \mathrm{Bu}$ dışlayıcılık onurun öznelerini belirlerken dayanılan otonom ve rasyonel birey olma şartı bakımındandır. Bu konuda felsefi bir tartışma için bknz: SCHROEDER, Doris, "Human Rights and Human Dignity", Ethical Theory and Moral Practice Y1l: 2012, Cilt: 15, Say1: 3, s.330. 
hukuki belgelerde yerini alması esasen oldukça yakın bir tarihi bulur. ${ }^{14}$ Yine denilebilir ki, Bildirge, adeta gerekçelendirilme ihtiyacından azade bir onur idealine dayanmaktadır. Buna, 'varlığı' konusunda uzlaşılan ancak 'neliği' konusunda tartışmaya gerek duyulmayan bir ideal de denilebilir. Öte yandan, insan onuruna ilişkin bu uzlaşı, kavramı yalnızca evrensel insan hakların felsefi bir gerekçesi olmak bakımından metinsel düzeyde ve sorgulama etmeksizin kabul etmiş olmakla sınırlı kalmaktadır. İnsan haklarına ilişkin bölgesel sözleşmeler ve anayasal metinler devreye girdiğinde, bu metinlerde ve bu metinler aracılığıyla korunan sistemlerde insan onurunun farklı görünümleri de belirecektir. Bütün bu farklı yaklaşımlar göz önünde tutulduğunda ise insan onurunun, hakların kaynağı olmak konusundaki görevi bir yana, tek tek hangi haklarla sıkı bir ilişki içinde olacağı, başı ıaşına bir hak olup olmadığı ve dahası ne türden hak taleplerini ve ihlallerini gidermek adına rol oynayacağı tartışmaları ortaya çıkacaktır.

O hâlde denilebilir ki insan onuru ve insan hakları arasındaki ilişki ardında bir dizi soru bırakmaktadır. Bu çalışma özelinde bu sorulardan önemli olanı ise: kavramının insan hakları hukuku yargılamalarında başvurulmak bakımından faydalı bir argüman olup olmadığı ve bir argüman olarak rol oynadığı durumlarda hangi haklarla etkileşim içinde olduğudur. Bu bakımdan öncelikle aşağıda insan onurunun yargılamalarda rol oynayan bir unsur olarak ele alınması gerektiğini destekleyen ve desteklemeyen çeşitli görüşler ele alınmaktadır.

Andrew Clapham, insan onuruna ilişkin hukuki kaygıların en az dört noktaya hizmet etmesi gerektiğini belirlemiştir. Bunlar: 1) Her türlü insanlık dışı muamelenin, aşağılanma ve utancın yasaklanması, 2) Her bireyin kendini gerçekleştirme, otonomi ve tatminine ilişkin bireysel tercihlerin garanti altına alınmas1, 3) Grup kimliği ve kültürün tanınıp korunması, 4) Her insan için temel ihtiyaçların karşılanacağı koşulların

$14 \mathrm{Bu}$ anlamda tartışma yaratan iddialardan biri Moyn tarafından ortaya atılmaktadır. Moyn'un iddiası Avrupa ekseninde ve anayasalcılığında, seküler bir liberalizm gelecek vaat edemeyeceği için, Hristyan değerlerine sadık bir liberalizm inşaası için insan onuru kavramının ortaya koyulduğudurve buna ilk örnek olarak da İrlanda Anayasasını göstermektedir. Daha fazlası için bkz: MOYN Samuel, "The Secret History of Constitutional Dignity", Yale Human Rights and Development Journal, Y1l:2014, Cilt: 17 , Say1:1, s. $40-44$. 
yaratılmasıdır. ${ }^{15}$ Öte yandan insan onurunun kullanımına ilişkin pratikte karşılaşılan tezatlıklar göz önüne alındığında bu eşiğin idealist ve fazlaca unsuru bir arada bulunduran bir eşik olduğunu söylemek mümkün olabilir.

İnsan onurunun salt hukuki bir prensip olarak ele alınması gerektiğini savunan Barrosso da, yasal bir prensip olarak alınacak olduğunda, hukuki amaçlar çerçevesinde üç farklı biçimde karşımıza çıkacağını belirtir. Bunlardan ilki: insanların sahip olduğu özel yeri korumak amaçlı içkin bir değer olarak ele alınmasıdır. İkincisi: her insanın eşit ve özgür bir kişi olmasından bahisle, kendi seçimlerini yapabilmesi ve kendi iyisini belirleyebilmesidir ki bu kavramın otonomi olarak ele alınması demektir. Son olarak, yazarın önerisi kavramın bir toplumsal değer olarak ele alınmasıdır; ancak bu sonuncu önerme, bizzat yazarın da dikkat çektiği üzere, paternalist ve ahlâkçı tehditleri barındıracağından titizlikle ele alınmalıdır. ${ }^{16}$

O hâlde insan onurunun hukuki yargılamalarda bir argüman olarak kullanılmasını destekleyen görüşler kavramın belirli ve sınırlı bir biçimde değil de, birden fazla alanı koruyacak biçimde ele alınması gerektiğini destekler görünmektedir.

McCrudden ise yukarıdaki görüşün aksine, ayrıntılı bir tartışmanın ardından vardığg noktayı, insan onuru kavramının insan haklarının hukuki uygulamalarında pek faydalı bulmamak olarak dile getirir. Zira kavram yargılamalara göre değişen ve üzerinde uzlaşının zor olduğu bir özellik taşımaktadır. İnsan onurunun kavramsal olarak insan hakları bakımından oynadığı önemli rolü inkâr etmemekle birlikte, hukuki kullanımının yargılamalar bakımından "manipülatif" bir rol oynadığını belirtir. Bu tespite paralel olarak verilebilecek bir örnekse Kanada Anayasa Mahkemesinin 2008 yılında ayrımcılık yasağı kapsamındaki davalarda bundan böyle insan onuru kavramına yer verilmemesi gerektiğine ilişkin tespitidir. Kanada Haklar ve Özgürlükler Yasası'nın eşitlik konusuna ayrılan kısmı, uygulamada bir ayrımcılık davasını ele alırken, söz konusu ayrımcılığın insan onuruna aykırı olup olmadığını araştırma kriterini getirmektedir. Bununla birlikte R. v. Kapp davasında hâkimler insan onurunun, yasanın eşitlik bölümün özünü oluşturan bir değer olarak hayati bir önemi olduğunu vurgulamış,

15 CLAPHAM, Andrew, Human Rights Obligations of the Non State Actors, 2006, s. 538.

16 BARROSSO, 2012, s.70. 
ancak hukuki olarak kavramın kafa karıştırıcı ve uygulanması zor bir külfet olduğunu dile getirmişlerdir. ${ }^{17}$ McCrudden, insan onurunun hukuk düzleminde sadece yerel insan hakları algısı ve yorumunu yansıtmakla kalmadığını, aynı zamanda bunu gerektirdiğini de söyleyerek, bu anlamda insan onuru hukuki bir sav olarak kullanıldığında kendi insan hakları pratiğini de beraberinde getiren bir araç olma niteliği taşıdığını söylemiştir. ${ }^{18} \mathrm{Bu}$ tespit, insan haklarını ve özgürlükleri içselleştirmiş ve toplum yaşantısının bir parçası haline getirmiş toplumlar ve yasal uygulamaları bakımından daha az sorun yaratacakken, henüz bir insan hakları kültürü oturtamamış toplumlar bakımındansa, onur kavramının insan haklarına üstünlüğü ile sonuçlanabilecek kimi sonuçlar yaratabilecektir.

McCrudden'in aksine Habermas, tam tersine insan onurunun hukuki alandaki rolünün belirsiz olmadığını, hatta insan onurunun neyin demokratik ve anayasal olup olmadığına ilişkin bir "sismograf" görevi gördüğünü ifade etmiştir. ${ }^{19} \mathrm{Bu}$ iki görüş, hem konuya bir felsefeci ve pozitif hukukçunun farklı bakış açılarını yansıtmak, hem de Avrupa ve Amerikan yargılarında insan onuruna atfedilen değer farkını ortaya koyabilmek için önemlidir. Bugün insan onuru konusu üzerinde kafa yoran düşünürler, insan onurunun Avrupa yargısındaki görünümünün Amerikan yargısı ve değerleri bakımından aynı rolü oynayıp oynamayacağı, iki kıtanın kendine özgü öne çıkan değerleri olduğu görüşünden hareketle, insan onuru konusunda minimum bir uzlaşıdan bahsedilip bahsedilemeyeceği sorusu etrafında dolanmaktadırlar. ${ }^{20}$

Yine kavramın hukuki kullanımına yönelik şüpheyle yaklaşan bir isim olan Gearty, insan onurunun tarihsel olarak türlü çeşit kullanımlara maruz kaldığına dikkat çeker ve bunlar arasında bir uzlaşmanın mümkün olamayacağını dile getirir. Gearty bu sonuca her ne kadar Birleşik Krallık yargısı özelinde varmış olsa da, yazara göre bir mahkemede kullanılması bakımından en önemli sorun, birbiriyle çelişen insan onuru yorumları olduğunda 'gerçek' bir tanıma kimin karar verecek olduğudur. Bu bakımdan

\footnotetext{
$17 \quad R$ v. Kapp, 2008.

18 MCCRUDDEN, 2008, s. 720.

19 HABERMAS, 2010, s. 469.

20 RAO, 2008, s. 75,79.
} 
mahkemelerin gözü kapalı bir biçimde bu kavrama yaslanmamaları gerektiği gibi, aynı zamanda da insan onurunun kararları etkileyeceği durumlar yasalarda somutlaştırılmalı ve buradan çıkan kararlar kesin ve ileriye etki edecek türde olmaktan ziyade her tek duruma özgü olmalıdır. ${ }^{21}$

$\mathrm{Bu}$ bakımdan çalışma, yukarıda yer verilen görüşlerin ardından sırasıyla kavramın insan hakları belgelerindeki yeri ve biçimine, bunu takiben de söz konusu belgelerin norm olarak alındığı yargılamalardaki örneklerine bakarak, konu edinilen tartışmaların somutlaşmasını sağlamaya çalışacaktır.

\section{ULUSLARARASI INSAN HAKLARI HUKUKUNDA INSSAN ONURU}

\section{A. Evrensel Belgeler Bakımından}

İnsan onurunu kavramı, ilk olarak 1944 yılında Uluslararası Çalışma Örgütü'ne (ILO) ait, aynı zamanda örgütün anayasasının da bir parçası olan Philedelphia Bildirgesi'nde yer almış olsa da ${ }^{22}$; kavram esas görünürlüğünü 1948 yılında kabul edilen Evrensel Bildirge ve Birleşmiş Milletler Kurucu Sözleşmesi’nin (BM Şartı) giriş kısımlarında yer almasına borçludur. Kurucu Sözleşme, kavrama giriş kısmında; varoluş amaçları bağlamında yer verirken, Evrensel Bildirge, gerek giriş kısmı ve birinci maddesinde gerek sosyal güvenlik ve çalışma hakkına ilişkin maddelerinde kavrama yer vermiştir. $\mathrm{Bu}$ bakımdan, 'onur' kavramı Bildirge'de karşımıza çeşitli yönleri ile çıkmaktadır. Giriş kısmı ve birinci maddede, "insanlık ailesinin tüm üyelerinin doğal yapısında ve eşit olarak bulunan bir değer" olarak çıkması bakımından içkin bir değeri; ekonomik sosyal ve kültürel haklar bağlamında ise "herkes insan onuru ve kişiliğin özgür gelişmesi bakımından vazgeçilmez olan ekonomik, toplumsal ve kültürel haklarının gerçekleştirilmesi hakkına sahiptir” ifadesinden anlaşılan haliyle, gelişebilen, dinamik bir durumu ifade eder görünmektedir.

21 GEARTY Conor, "Socio-Economic Rights, Basic Needs and Human Dignity”, Understanding Human Dignity içinde (editör McrCrudden) Oxford University Press, 2013, s.155-173.

$22 \mathrm{Bu}$ aynı zamanda insan onurunun ilk olarak sosyal haklarla ilişkisi bakımından da evrensel belgelerde yer almasi demektir. https://www.ilo.org/legacy/english/inwork/cb-policyguide/declarationofPhiladelphia1944.pdf (erişim 28.01.2019) 
1949 Cenevre Konvansiyonları'nda da insan onuru kavramını görmek mümkündür. $\mathrm{Bu}$ Konvansiyon'da ve insan hakları belgelerinin genelinde, onur kavramının bilhassa alçaltıcı muamele ve işkenceye ilişkin maddelerde yer bulması, kavramın içkin ve sabit olmanın ötesinde bir kavram olduğuna işaret ederken; yalnız barış zamanı değil, savaş zamanı da gözetilmesinin önemine işaret etmektedir. ${ }^{23}$ Evrensel Bildirge'yle görünürlük kazanan insan onuru kavramı, 1960'lı yıllara gelindiğinde ortaya çıkacak bir dizi yeni insan hakları sözleşmesinde de yer bulmaya devam etmiştir. Kavram, bu sözleşmelerin hem başlangıç kısımlarında hem de bilhassa bireysel özgürlükler ve özgürlüğün kısıtlanmasına ilişkin maddelerinde yer almıştır.

İnsan onuru, Birleşmiş Milletler İkiz Sözleşmeleri olarak anılan sözleşmelerden Sivil ve Politik Haklar Sözleşmesi’nde: bizzat özgürlüğünden mahrum olan bireyleri de gözetecek biçimde vurgulanmış ve yine bir diğer sözleşme olan Ekonomik, Sosyal ve Kültürel Haklar Sözleşmesi’nde hem eğitim hakkı hem de eğitimin amacı ile ilişki içinde ele alınmıştır. Kavrama, Her Türlü Irk Ayrımcılığının Ortadan Kaldırılması Sözleşmesi’nde, Kadına Karşı Her Türlü Ayrımcılığın Engellenmesi ve Birleşmiş Milletler İşkencenin Önlenmesi Sözleşmesi'nde yer verilerek, daha yakın dönemlerde bunu sırasıyla Çocuk Hakları Sözleşmesi, Göçmen İşçiler ve Ailelerinin Haklarına İlişkin Sözleşme ve Engelli Bireylerin Insan Hakları Sözleşmesi takip etmektedir. 1989 tarihli BM Çocuk Hakları sözleşmesinin 23. maddesi, engelli bireylerin hakları bakımından bağlayıcı bir sözleşmede görünüm kazanan ilk madde olma özelliğinin yanı sıra, sözü geçen madde devletlere "fiziksel ve zihinsel engelli çocukların insan onurunun sağlanacağı bir yaşamı” da sağlama ödevi yüklemektedir. Yine Sözleşme'nin 28. maddesi, çocuğun eğitim hakkına ilişkin olup "çocuğun insan onuru” şeklinde bir kavrama yer vermiştir. Çocuğun onuru kavramı Sözleşme’nin işkence ve cezalandırmaya ilişkin maddelerinde de yer almaktadır. 2007 tarihli Engelli Kişilerin İnsan Hakları Sözleşmesi de insan onurunu gerek Sözleşme ile korunup güçlendirilmesi gereken bir değer gerekse bireysellik, potansiyel ve özerklikle birlikte ele alınıp sağlanması ve korunması gereken bir özellik olarak ele almıştır. Bu noktada çocuk

23 MCCRUDDEN, Christopher, "Human Dignity and Judicial Interpretation of Human Rights", The European Journal of International Law, Y1l: 2008, Cilt: 19, Sayı: 4, s. 668. 
hakları ve engelli kişilerin insan hakları sözleşmelerinde yer alan 'onur' kavramından yola çıkarak, bu onur anlayışının mutlak bir otonomi ya da akılcılık üzerine inşa edilen bir insan onuru anlayışını yansıtmadığını söylemek mümkün olacaktır. Bilhassa örnek verilen sözleşmeler ekseninde ortaya çıkan bir nokta insan onurunu sadece içkin ve hakları üzerine inşa ettiğimiz bir değer olarak almanın ötesinde, söz konusu onurun kırılganlığını, insan haklarında rol oynayan diğer prensiplerle olan ilişkisini ve dolayısıyla korunmaya olan ihtiyacını da dile getirmektedir.

1997 tarihli Unesco İnsan Genomu ve Insan Haklart Bildirgesi’nde de, insan onuru kilit kavramlardan biri olarak ortaya çıkmaktadır. İnsan onuru ve insan genomu arasındaki ilişkiye özel bir bölüm ayıran Bildirge, biyoetik ve insan hakları alanına ilişkin bir dizi tartışmayı da beraberinde getirmiştir. Örgüt, 2011 yılında konuya ilişkin geçmiş yargılamalardan yola çıkarak bir hükümler kitabı yayınlamıştır. Bu çalışmada insan onuru, Unesco Bildirgesi'nde konu edilen haliyle tıbbi destek, ötenazi, aş1lama, tedavi seçme ya da reddetme, zihinsel engellilerin tedavisi ve benzeri başlıklar üzerinden örnek davalarla tartışılmıştır. ${ }^{24}$

Birleşmiş Milletler Genel Kurulu da yorum ve yönergelerinde, insan hakları belgeleri ve yönergelerinin insanın onuru ve değerinden türetilmesi gerekliliğine işaret etmiştir. Örneğin 1993 yılı Viyana Konferansı ve Eylem Planı Belgesi, insan onurunun insan hakları açısından kurucu bir öğe olarak ele aldığını, insan kişisinin insan haklarının temelinde yatan şey olduğunu ve insan onurunun bu bakımdan önemini yinelemiştir. Bununla beraber eylem planı çıktısında, insan onuru kavramının ayrıca; işkence, yerli halkların hakları, cinsiyet temelli şiddet, yoksullukla mücadele ve biyoetik alanına ilişkin maddelerde de göz önünde tutulacağını belirtmiştir. ${ }^{25}$

\section{B. Bölgesel Belgeler Bakımından}

Uluslararası insan haklarında olduğu kadar bölgesel insan hakları belgelerinde de önem ve görünürlüğ̈̈ giderek artan insan onuru, Avrupa, Amerika, Arap, Afrika insan hakları mekanizma ve belgelerinde yer bulmuştur. 1948 tarihli Amerikan İnsan Hakları

24 Casebook on Human Dignity and Human Rights, Unesco, 2011.

25 Viyana Eylem Planı 1993 https://www.ohchr.org/EN/ProfessionalInterest/Pages/Vienna.aspx (erişim 01.07.2019) 
Bildirgesi 'nde işkence ve kölelik yasağı ve özel hayatın gizliliğine ilişkin maddelerde görülen insan onuru, 2008 yılında yürürlüğe giren Insan Hakları Arap Şartı'nın giriş kısmında, insanların "Tanrı tarafından yaratılmış olma onurlarına dayanarak" ifadesiyle ele alınmıştır. ${ }^{26}$ Yine bu Şart aracılığıyla kavram, her türlü ırkçılık, Siyonizm, yabancı işgal ve egemenliğinin insan onuruna zarar vereceği şeklinde ele alınmış, bununla birlikte kadın erkek eşitliği, çocuk ve engelli hakları ve özgürlükten yoksun bırakılmaya ilişkin konuları düzenleyen maddelerde bu kavram rol oynamıştır. İslam İşbirliğgi Teşkilatı'nın, İslam ülkelerinin insan hakları konusundaki tutumunu yansıtan bölgesel bir belge olan ve 1990'da kaleme alınan Kahire Bildirgesi'nde de "insan onuru" kavramına yer verilmiştir. Her şeyden önce insan haklarını ele alış ve yorumlamada şeriat kurallarının temel alınacağını sayısız maddesinde ortaya koyan ve bunu 25 . maddesinde açıkça belirten bu bildirgede, insan onuruna dört kez değinilmektedir. ${ }^{27} \mathrm{Bu}$ kullanımlara bir örnek, Bildirge'nin giriş kısmında ele alınan "İslami kurallara uygun bir onurlu yaşam hakkı" ifadesi olacaktır. Bu anlamda bu bildirgede yer alan onur anlayışı bizzat İslami bir tanımdan yola çıkılarak yapılmamışsa da burada rol oynayacak onurun Bildirge'nin bütününe egemen olan teolojik anlayışın dışında kalamadığı anlaşılmaktadır.

1986 tarihinde yürürlüğe giren Insan Hakları Afrika Şartı'nda (Banjul Charter) da kavramın içkin bir değer olarak kabul edildiğinin belirtilmesi dışında, Afrika halklarının halen bir özgürleşme ve onurlarını kazanma mücadelesinde oldukları hususuna yer verilmiştir. Bu bakımdan insan onuru, bu belgenin giriş kısmında sömürgecilik, yeni sömürgecilik, apartheid ve Siyonizm'le mücadelede bir unsur olarak da belirmektedir. Kavram bunun haricinde sözleşmenin 5. maddesinde 'hukuki kişilik' ve 'kölelik' bağlamında yer almaktadır.

1969 tarihli Amerikalılar Arası İnsan Hakları Sözleşmesine gelinecek olduğunda, insan onurunun insanlık dişı muameleyi, kölelik ve zorla çalıştırma yasağını ve mahremiyet hakkını düzenleyen maddelerde görünüm kazandığı görülür. Bunun dışında

26 Insan Haklart Arap Şartı http://www.humanrights.se/wp-content/uploads/2012/01/Arab-Charter-onHuman-Rights.pdf (erişim: 01.07.2019)

27 http://hrlibrary.umn.edu/instree/cairodeclaration.html (erişim: 01.07.2019) 
Amerikan İnsan Hakları Mahkemesi kararlarına, insan onurunun bilhassa sosyal ve ekonomik hakların gerçekleşmesi ile olan ilgisi yansımakta ve bu mahkemenin kararlarında salt insan onuruna değil aynı zamanda insan onuruna uygun bir yaşam hakkına referans yapılmaktadır. ${ }^{28}$ Bu nokta, insan onurunun olası bir sosyal ve kültürel okumasında, çerçeveyi sosyal ve ekonomik haklarla çiziyor olması bakımından önemlidir.

İnsan onuru kavramının Avrupa özelinde bilhassa kıtanın anayasacılık anlayışı bakımından ayrı bir yerde durduğu söylenebilir. ${ }^{29}$ Şüphesiz bunda rol oynayan etkenlerden en önemlisi ikinci Dünya Savaşının kıtada yarattı̆̆ı atmosfer ve insan onurunun öneminin yaşayarak öğrenilmesidir denilebilir. ${ }^{30}$ Olayların beşiğinde olan bir ülke olması bakımından Alman Anayasası, varoluş amacını bizzat insan onuru kavramına dayanmaktadır. $\mathrm{Bu}$ anayasa, 1. maddesinin, ilk fikrasında insan onurunun dokunulmaz olduğunu, buna saygı gösterilmesinin ve korunmasının tüm kamu otoritelerinin görevi olduğunu belirterek başlar. Alman Anayasası'nda mevcut olan diğer haklar her zaman bu ilk maddede yer alan değerin 1şığında yorumlanacaktır. Bu anlamda Alman mahkemelerinin yaptığı hukukun bir anlamda insan onurunun hukuku olduğunu söylemek yanlış olmaz. ${ }^{31}$. McCrudden, Avrupa anayasalarında kavramın yer alışına ilişkin olarak 1940’lı yılları kapsayan dönem ile diktatörlüklerin yıkılmasını ardından gelen 70'li dönemleri birbirinden ayırır. Buna paralel olarak İtalya, Yunanistan ve İspanya gibi ülkeler 70'li yıllarda onur kavramını anayasalarına sokmuşlardır. 90'lı yıllarda Soğuk Savaşın sona ermesiyle Doğu Avrupa ülkelerinin anayasalarında da bu kavrama yer verilmeye başlanacaktır. ${ }^{32}$

Avrupa anayasacılığı bakımından insan onuru yukarıda belirtilen bir öneme sahip olsa da, Avrupa Konseyinin en önemli insan hakları metini olan Avrupa İnsan Haklarl Sözleşmesi'nde insan onuru kavramına rastlanmamaktadır. Durum metinsel bakımdan

\footnotetext{
28 Villagran-Morales et al. v. Guatemala, 1999

29 DUPRE, Cathrine, The Age of Dignity, Hart Publishing, 2015, s.61.

30 DUPRE, 2015, s.61.

31 CHASKALSON, Arthur, "Human Dignity as a Constitutional Value", The Concept of Human Dignity in Human Rights Discourse (ed. D.K. Klein) 2002, s.136.

32 MCCRUDDEN, 2008, s. 664
} 
böyle olsa da, Dupre, kavramın Sözleşme bakımından son derece önemli olduğunun altını çizmekte ve Sözleşmenin; öldürme, işkence ve insanlık dışı muamele ve kölelik ve zorla çalıştırma yasağına ilişkin iki, üç ve dördüncü maddelerinin tam olarak insan onurunu korumaya yönelik maddeler olduğunu belirtmektedir. ${ }^{33}$ Bunu destekler biçimde, Avrupa İnsan Hakları Mahkemesi, insan onurunu S.W v. Birleşik Krallık davasında belirttiği üzere "yargılamanın kalbi”" olarak ele almış ve onurun korunması hususunun bir "uygarlık sorunu" olduğunu dile getirmiştir. ${ }^{34}$ Mahkeme bakımından onur, daha çok içtihatlarla ortaya çıkarılan bir özellik taşımaktadır. Söz konusu içtihatlar işkence ve kötü muamelenin önlenmesinden, özel hayatın gizliliğine varan konulara uzanabilmekle birlikte, mahkemece referans alınan onur, normatif bir tanım üzerinden değil, hâkimlerin ele alıp uygulayışı bakımından, hukuki bir görünüm kazanmaktadır.

Bölge bağlamında, insan onuru, pek çok Avrupa Konseyi sözleşmelerinde ve bunlardan biri olan Gözden Geçirilmiş Avrupa Sosyal Şartında karşımıza çıkmaktadır. Bilhassa, Avrupa Konseyi Biyotıp ve İnsan Hakları Sözleşmesi giriş kısmında belirtildiği üzere, insan onuru hem kişiye hem de insanlık ailesine içkin bir değer olarak ele alarak koruma sağlayan bir nitelikte olması bakımından önemlidir. Öte yandan Sözleşmede insan onurunun koruma alanı, henüz hayata gelmemiş insanları da kapsayacak biçimde geniş ele alınmıştır.

Avrupa Birliği düzeyine gelinecek olduğunda ise göze çarpan en önemli belge Avrupa Birliği Temel Haklar Şartı olacaktır. Bu belge kendi içinde ayrıldığı başlıklar bakımından birinci başlığı 'insan onuru' başlığı olarak düzenlemiş; yaşam hakkı, bedensel ve ruhsal dokunulmazlık hakkı, işkence ve kötü muamele yasağı ve zorla çalıştırma ve kölelik yasağına ilişkin maddeleri bu başlık altında toplamıştır. Bedensel ve ruhsal dokunulmazlık, bilhassa Sözleşme bakımından kişilerin seçilerek ayrılmasını amaçlayan insan ırkının soyaçekim yoluyla 1slahına yönelik uygulamaların yasaklanması, insan bedeninin ve bölümlerinin ticari bir kazanç kaynağı haline getirilmesinin yasaklanması ve insanların kopyalama yoluyla üretilmesinin yasaklanması konularına ilişkindir. Dupre’ye göre kavramın bu şartta yer almasıyla

\footnotetext{
33 DUPRE, 2015, 64.

34 S.W v. UK $(20166 / 92)$
} 
insan onurunun kullanım ve gelişimi için yeni bir dönem başlamıştır. Üstelik, yazarın ifade ettiği üzere 2009 Lizbon Anlaşmasıyla kavram, Şart'ın ilk maddesi olmanın ötesinde Avrupa birliğinin de temel değeri haline gelmiştir. Bu bakımdan Dupre 2009 yılını insan onurunun normatif önemi açısından hiç olmadığı kadar önemli olan bir zaman dilimi olarak tanımlar ve bu tarihi Avrupa anayasacılığ iç̧in bir dönüm noktası olarak ele alır. ${ }^{35}$

$\mathrm{Bu}$ bölüme ilişkin bir değerlendirmeden ortaya çıkacak yorum, evrensel nitelik taşıyan ve BM belgelerinde yer bulan insan onuru kavramının önceleri insan haklarına evrensel bir zemin sağlamak amacıyla ve daha ziyade içkin bir insani özellik olarak ele alınmış olduğu (insanlık ailesine mensup olmaktan ve bu anlamda değerli olmaktan ileri gelen bir onur) ancak zaman içinde farklı haklar özelinde de konu olmuş olduğu; sağlık, çalışma, barınma, iyi bir yaşam gibi hakların varlığını gözetirken ve yokluklarından söz ederken gözetilen bir standart olduğudur. Diğer yandan bölgesel düzeye gelinecek olduğunda insan onurunun toplumsal kültürel özelliklerinin bu belgelerdeki yansımasını da görmek mümkündür. Bu bakımdan hukuken telaffuz edilen onurun arka planında Avrupa özelinde gerçekleşmiş bir soykırım gerçeği ve otonom bir birey kavramını, Güney Amerika ve Afrika özelinde kölelik gerçeği ve topluluk bilincini, İslam coğrafyası özelinde dini referansların ve bunun yön verdiği bir toplumsal onuru barındırdığı gözlemlenebilir. Bu bakımdan bölgesel insan hakları belgelerinin insan onurunu ele alma, koruma ve yorumlama biçimleri bir ölçüde bu coğrafyaların tarihsel, kültürel ve sosyo-ekonomik arka planından bağımsız bir nitelik taşıyor görünmemektedir. $\mathrm{Bu}$ da insan onuru argümanın nasıl ve ne şekilde kullanılacağı ve etkinliği sorusunu yinelemeyi gerekli kılmaktadır.

III. BELGELER IŞIĞINDA INSAN ONURUNUN EVRENSEL VE AVRUPA DÜZEYINDEKİ ÇEŞITLI DAVALARDA ELE ALINIŞ VE YORUMLANIŞI

35 DUPRE, 2015, Supra 33. 
Buraya kadar ele alınanlar çerçevesinde insan onurunun, felsefi arka planı bir yana, uluslararası belgelerde bir temellendirme aracı ya da bir değer olarak ortaya çıkabildiğini ve daha çok metinsel bir unsur olarak yer aldığını söylemek mümkün olacaktır. Bu noktadan itibarense kavramın prosedür hukuku bakımından ele alınması, hukuk aracılığıyla gerçeklenmesinin mümkün olup olmadığı ve bunun ne şekillerde görünür olduğu sorusu ele alınacaktır. Buradaki amaçsa, kavramın bölgesel ve evrensel yargılama sistemlerindeki farklı kullanımlarına örnekler sunarak, nihayetinde kavram etrafında beliren belirsizlik ve sorunlara işaret etmek olacaktır.

\section{A. Evrensel İnsan Hakları Yargılamaları Bakımından}

Hali hazırda evrensel bir insan hakları mahkemesi olmadığından hareketle, kavramın evrensel yargılamalardaki yeri Birleşmiş Milletler Sözleşmelerine bağlı koruma mekanizmalarına bağlı bireysel şikâyetler yoluyla ele alınabilir. Bunlardan önemli biri Birleşmiş Milletler Sivil ve Politik Haklar Sözleşmesine bağlı olan İnsan Hakları Komitesi önüne gelen şikâyetler ve bu yönde verilen kararlardır. Bu komite önüne gelen ve insan onuru kavramı etrafında dönen ilginç bir dava geçmişe ait bir dava olan Wackenheim davasıdır. Bay Wackeinheim, Paris yakınlarında bir gece kulübünde gerçekleşen ve kişiyi korunaklı bir elbise giydirerek mümkün olduğunca en uzağa firlatmak amacı güden "cüce firlatma oyunu" olarak bilinen bir oyunda yer almak isteğinin, Vali tarafından yasaklanması üzerine, olayı dava konusu etmiştir. Vali, oyunu kamu düzeni ve sağlığını etkilediği gerekçesiyle yasaklatmış, Bay Wackeinheim da bu yasağı mahkemeye taşımıştır. Birinci derece mahkeme, oyunun, dayanılan kamu düzeni ya da sağlığı argümanlarından birine ilişkin bir tehdit içermediğini belirterek yasağı yersiz bulmuştur. Ancak temyize taşınan bu davada Yüksek Mahkeme, "kamu düzeni" kavramının geniş bir yorumunun insan onurunu da kapsayabileceği sonucuna varmış ve yasağın yasal olduğunu belirtmiştir. Yüksek Mahkeme, kararında, engelli bir kimsenin kullanılmasının söz konusu olduğunu, bunun bir amaç olarak ele alınması gereken insanın onurunu ihlal ettiğini belirtmiştir. Öte yandan Bay Wackeinheim konuyu Fransa'nın da imzaladığı Birleşmişs Milletler Sivil ve Politik Haklar Sözleşmesi'nin bir organı olan İnsan Hakları Komitesi'ne taşımıştır. Bu noktada ilginç olan, bu başvuruda Bay Wackeinheim'ın da kendi savını insan onuru üzerinden yürütmüş olması, 
kendisinin çalışma hakkına ilişkin seçim yapabilme ve otonomisinin engellendiği gerekçesiyle insan onurunun çiğnenmiş olduğunu ileri sürmüş olması olmuştur. $B M$ Sivil ve Politik Haklar Sözleşmesi insan onuru ya da çalışma hakkını ayrı bir maddeyle ele almadığından, konuyu ayrımcılık yasağı kapsamında incelemiş ve bu konuda bir aykırılık bulmamıştır. Bu dava, insan onuru konusuyla ilgilenenler bakımından oldukça ilginç bir dava olma niteliği taşımaktadır. Kimileri, davanın insan onurunu "toplumsal bir değer" olarak ele alan anlayışı yansıttığını dile getirirken, kimileri bunu maddi bir insan onuru anlayışıly ilişkilendirmişlerdir ${ }^{36}$ Diğer yandan Rosen, sözü edilen faaliyetin onur kırıcı olduğuna şüphe olmadığına, ancak bu türden örneklerin çoğaltılabileceğine ve her durumda bir yığın etkinliğin yasaklanması gerekebileceği gerçeğine işaret etmektedir. Rosen, bu noktada, dolaylı olarak "hukukun görevinin insanların kendini onur kırıcı durumlara düşürmesini engellemek mi” olduğu gibi zor bir soruyla da karşı karşıya kaldığımızı belirtmektedir. ${ }^{37}$ Rosen, Wackenheim davasının, tam da insan onurunun mevcut hukuk düzenindeki belirsiz ve kaygan konumuna bir örnek olduğuna işaret etmiş ve bu davayı, kavramın uzlaşıdan uzak ve kafa karıştırıcı olduğuna ilişskin yerinde bir örnek olarak değerlendirmiştir.

İnsan onuru, ele alınış biçimine göre sadece hak türeten değil, aynı zamanda kimi ‘özgürlüklerin' de önüne geçen bir tez olabilmektedir. İnsan onuru ve ifade hürriyeti çerçevesinde getirilebilecek sınırlandırmalar bilhassa Avrupa özelinde nefret söylemi çerçevesinde gündeme gelmektedir. Nefret söylemi bağlamında insan onuru yaklaşımının geçmişte gündeme geldiği en bariz dava Faurisson davası olmuştur. Soykırım inkârına ilişkin faaliyetler yürüten Faurisson'a Fransız mahkemelerince yöneltilen suçlamaların, bir insan hakları ve ifade özgürlüğü ihlali olmadığına, aynı zamanda BM İnsan Hakları Komitesi de katılmış ve bu sonuca varılmasında, karara düşülen bireysel yorumlarda ayrıca ifade edilen insan onuru kavramı ve kavramın antisemitizm ile ilişkisi önemli bir rol oynamıştır. ${ }^{38}$

\footnotetext{
36 LUCY, Michael, "Defining Dignity and its Place in Human Rights" New Bioethics, Y1l: 2014 Cilt: 20, Sayı:1, s. 24.

37 ROSEN, Michael, Dignity: Its History and Meaning, s. 67-71.

38 Robert Faurisson v. France, Communication No. 550/1993
} 


\section{B. Avrupa Bölgesel Yargılamaları Bakımından}

Avrupa Konseyi bağlamında insan onuru, Avrupa İnsan Hakları Mahkemesi (AİHM) kararlarında 1950 'den bu yana önemli rol oynamaktadır. AİHS'nin insan onuruna yazılı bir yer ayırmamış oluşu bu bakımdan bir önem arz etmez. Bu konuda mahkemenin öne çıkan ilk kararı Tyrer davası olup, bu davada Mahkeme on beş yaşındaki bir çocuğun mahkeme tarafından fiziksel bir cezaya çarptırılmasının 'insan onuruna bir saldırı’ olduğu kararını vermiştir.

AİHM'nin insan onuru savıyla karşı karşıya kaldığı bir dava yaşam hakkı bağlamında ele alınan Pretty v. Birleşik Krallık davası olmuştur. Boyundan aşağısı felçli olan ve tüple beslenen Bayan Pretty, yaşamda sayılı haftası kaldığını bildiğinden ve kendisini kaçınılmaz bir ölümün beklediğinden emin olduğundan, yaşamına "onurlu bir biçimde" son vermek istemesi gerekçesiyle, kendi fiziksel yetileri intihar etmesine olanak vermediği için, bu konuda kocasından destek almak istediğini belirtmiş ve savcılıktan kocasının kendi ölümünden sorumlu tutulmaması için bir garanti istemiştir. Bu isteği reddedilen Pretty, davayı AİHM'ne taşımış ve yaşam hakkı başta olmak üzere pek çok hakkının ihlal edildiğini ileri sürmüştür. AİHM verdiği kararda sözleşmede yer alan yaşam hakkının aynı zamanda bir "ölüm hakkı" olarak ileri sürülemeyeceğini belirterek davayı reddetmiştir. İnsan onuru, insan onuruna uygun bir tedavi ve onurlu bir biçimde yaşamına son verme kavramları başvurucu tarafından kendi lehine pek çok argümanla desteklenmişse de Mahkeme kendi gerekçeli kararında insan onurunun önemine değinirken yaşam hakkının kutsallığından yana bir vurguya da başvurmuştur. $\mathrm{Bu}$ anlamda söz konusu davada insan onuru argümanı, kavramın bilhassa biyo-etik tartışmalardaki problemli yerini akla getirir niteliktedir.

Mahkemenin yaşam hakkının fetüse uygulanıp uygulanmayacağını ele aldığı bir dava olan Vo. v. Fransa davasında, medikal bir yanlış sonucu anne karnında yaşam potansiyelini kaybeden bir fetüse ilişkin davada mahkeme, fetüsün de insan türüne ait olduğu ve bu bakımdan insanlık onuru nedeniyle korunması gerektiğini dile getirmişse de konunun yaşam hakkı bakımından ele alınamayacağını belirtmiştir. Bu örnekte Mahkemenin, bizzat Evrensel Bildirge'de de yer alan içkin bir insanlık onuru anlayışına dayandığgını görmek mümkündür. 
AİHM tarafindan insan onuru tezine başvurulan bir başka davaysa McDonald $v$. Birleşik Krallık davasıdır. Mahkeme, burada Pretty davasında içinden çıkamadığı 'onur' kavramının somutlaştırılması bakımından da önemli bir noktaya 1şık tutmuştur. Felçli bir kişi olan McDonald, geceleri tuvalet ihtiyacını giderebilmesi için sürekli bir yardımcıya ihtiyaç duymaktadır. Bu anlamda kendisine yerel otoriteler tarafindan ekonomik destek sağlanmaktadır. İlerleyen dönemlerde bu ekonomik desteğin McDonald'ın geceleri ped kullanabileceği gerekçesiyle aniden azaltılması üzerine başvurucu durumu İngiliz mahkemelerine taşımış ve insan hakları bağlamında özel hayatına ve insan onuruna saygı ilkesinin ihlal edildiğini öne sürmüştür. Ulusal düzeyde tatmin edici bir sonuç alamayan Bayan McDonald bunun üzerine davayı AİHM'ne taşımıştır. Mahkeme bu anlamda 8. madde kapsamında olan "özel hayata saygı" ilkesini geniş bir yorumla ele almış ve kararında, insan özgürlüğü ve onuruna saygının mahkeme için son derece esaslı noktalar olduğunu belirterek, "insan onurunun sadece çetrefilli davalarda değil, aynı zamanda günlük hayatı ilgilendiren destek ve bakım hizmetleri yönünden de önemli" olduğuna değinmiş ve yerel otoritelerin bu desteği çekmesinin kişinin "kendilik ve kişisel kimlik” alanlarını ihlal ettiğinden ötürü, özel hayata saygı prensibinin ihlalinin söz konusu olabileceğini belirtmiştir. ${ }^{39}$ Dava, kısmi bir süre için 8. maddenin ihlal edildiği kararıyla sonuçlanmıştır ve insan onuru ve engelli bireyler, insan onuru ve bakım hizmetleri arasındaki ilişkiyi mahkemenin yakın zamanda nasıl ele aldığını ortaya koymuştur.

Kölelik ve zorla çalıştırma yasağı kapsamında insan onuru, Siliadin v. Fransa davasında rol oynamıştır. Davada on sekiz yaşından küçük Afrika kökenli bir kişinin Fransız bir aile tarafından pasaportuna el konularak zorunlu ev içi hizmette kullanılması ulusal mahkemelerce yalnızca para cezasıyla sınırlı kalmış ve olay AİHM'sine taşınmıştır. Fransız devletinin Sözleşme'nin kölelik ve zorunlu çalıştırmaya ilişkin 4. maddesini ihlal ettiği gerekçesiyle açılan davada Mahkeme, söz konusu olayın modern bir kölelik olarak yorumlanıp yorumlanmayacağı tartışmalarında, başvurucunun kendini

$39 \quad 4241 / 12(2014)$ 
içinde bulduğu zorunlu çalışmanın insan onuruna aykırı olduğu yorumunda bulunmuştur. ${ }^{40}$

Transseksüel bir kişinin evlilik engeline ilişkin olan Goodwin v. U.K davasında insan onuru argümanı davanın seyrini etkileyecek derecede bir önem rol oynamasa da Mahkeme, 90. Paragraftaki yorumunda, Sözleşmenin temelinde yatan amacın insan onuru ve insan özgürlüğü olduğunu yinelemiş ve bu kavramları Sözleşmenin 8. Maddesiyle koruma altına alınan hakların otonom bir biçimde kullanımı ile özdeşleştirmiştir. Mahkeme, kararın 91. paragrafında, herkesin aynı değer ve onura sahip olduğu bir toplumun, farklı cinsel yönelimleri geride bırakmayacak şekilde tasarlanması vurgusunda bulunmuştur. ${ }^{41}$

AİHM genelinde insan onurunun en yaygın ve tartışmasız kullanımının kötü muamele ve işkenceye ilişkin davalarda görüldüğünü belirtmek de faydalıdır. ${ }^{42} \mathrm{Bu}$ bakımdan, Tekin v. Türkiye ve Selmouni v. Fransa davaları insan onuru ve Sözleşmenin üçüncü maddesi arasında ilişki kuran önemli kararlardır. Bunun dışında bir örnek Mouisel v. Fransa davasıdır. Olayda ileri derecede kanser hastası bir mahkûmun hastaneden cezaevine naklinin kelepçeli bir şekilde yapılmasını insanlık dışı muamele olarak ele almış ve eylemin insan onuruna aykırılığını dile getirmiştir. ${ }^{43}$

Buraya kadar ortaya konulan örnekler aracılığıyla, insan onurunun mahkeme bakımdan en çok yaşam hakkı, bilhassa işkence ve kötü muamele yasağı, zorla çalıştırma yasağı, özel hayata ve aile hayatına saygı ile ilgili 2, 3 ve 8 . maddelerle ilişki içinde ortaya çıktığını söylemek mümkündür. ${ }^{44}$ Kavram, başvurucular tarafından bir iddiayı desteklenmek için kullanabildiği gibi, mahkeme tarafından da bir ihlalin altını çizmek bakımından kullanılabilmektedir. Öte yandan mahkeme önüne gelen kimi insan hakkı ihlali iddialarını geri çevirirken de bizzat bu argümana dayanabilmektedir. ${ }^{45}$

$4073316 / 01(2005)$

$41 \quad 28957 / 95$ (2002)

42 Bouyid v. Belgium 23380/09 ; Svinarenko and Slyadnev v. Russia 32541/08 ve 43441/08

43 67263/01 (2002)

44 Ancak yalnızca bu maddelerle sınırlı değildir.

45 COSTA, Jean Paul, Human Dignity in the Jurisprudence of European Court of Human Rights, Understanding Human Dignity içinde, s. 400. 
Bununla birlikte belirtilebilecek bir başka nokta, Mahkemenin insan onuruna yaptığ atıfların bilhassa son yirmi yılda ciddi bir artış gösterdiğidir, ancak bunların başında da yine aşağılayıcı muameleye ilişkin davalar gelmektedir.

\section{Avrupa Birliği Bölgesel İnsan Hakları Yargılamaları Bakımından}

Yukarıda da ifade edildiği üzere, Avrupa Birliği hukuku insan onuruna en yüksek koruma ve değeri atfetme iddiasını taşır görünmektedir. Avrupa Birliği Anlaşmasının ikinci maddesi, Birliğin insan onuruna saygı üzerine kurulu olduğunu ifade etmekte ve AB Temel Haklar Bildirgesi ilk maddesini insan onuruna ve bu kavramla ilişkili haklara ayırmaktadır. Bu noktada Dupre ilginç bir noktaya dikkat çeker: AB Temel Haklar Şartı, yaşam hakkı ve insan onuru arasındaki hiyerarşide bir değişiklik yaratmıştır. Temel Haklar Şartında göze çarpan bir nokta insan yaşamına ilişkin maddenin, insan onuruna ilişkin maddeyi takiben yer almasıdır. Yazar, daha önceleri AİHS ve AİHM kararlarında insan yaşamına ve yaşamın kutsallığına ilişkin maddelerin ve buradan yapılan çıkarımların insan onuru kavramına öncelendiğini, ancak AB Şartıyla bu dengenin insan onurunun önemi ve üstünlüğü lehine döndüğünü belirtir. ${ }^{46}$ İnsan onurunu korumaya yönelik bu tutum Avrupa Adalet Divanı kararlarında da gözlemlenmektedir.

Bu konuda Divan önüne gelen ilk dava Hollanda'nın AB Parlamentosu ve Konseyine yönelik davasıdır. Davada, insan bedeninin ve organlarının patentleştirilebilmesi ve ilgili biyoteknolojik müdahalelerle bir araca dönüştürülmesinin önünü açtığı ve dolayısıyla insan onuruna uygun olmadığı gerekçesiyle, Hollanda tarafından ilgili AB Direktifinin uygunsuzluğu AB Adalet Divanına taşınmıştır. İlgili başvuru her ne kadar geçersiz bulunmuş olsa da Divan tarafından insan onurunun öneminin vurgulandı $\breve{g}_{1}$ bir dava olmuştur. ${ }^{47}$

İnsan onuruyla ilgili Avrupa Adalet Divanı önüne gelen bir başka dava Brüstle v. Greenpeace davasıdır. Kök hücre sağlanmasında insan embriyosu kullanan Alman bir

46 DUPRE, Constacting the meaning of dignity: four questions, içinde Understanding Human Dignity 2013, s.115

47 AVBELIJV, Matej, "Human Dignity and EU Legal Pluralism" içinde Research Handbook on Legal Pluralism and EU Law (eds. Davies, Avbelj) Edward Edgar Publishing 2018, s.97

Case C-377/98, The Netherlands v. Eu Parliement and the Council 
firmanın patentinin geçersiz kılınmasına ilişkin Greenpeace tarafından yürütülen davada, mahkemeden embriyonun ne demek olacağına ilişkin hukuksal bir tanım getirilmesi istenmiştir. Bu karar aracılığıyla Mahkeme "insan onurunun” biyoteknolojik gelişmelerle denge halinde tutulması gereken bir kavram olduğunu belirtmiştir. ${ }^{48}$

Divana yansımış bir diğer ses getiren dava Alman yargısından doğan Omega davasıdır. $\mathrm{Bu}$ dava, insan onurunun hukuki kullanımı açısından ulusal anayasa ve yorumlarla, Birlik hukuku arasında nasıl bir ilişki ve denge olabileceğini ortaya koymak bakımından önemlidir. Alman mahkemesi, İngiltere menşeli kurgusal ve oyun amaçlı bir öldürme aracı olan (lazer bir tabanca) omega 'nın, insanları öldürmeyi teşvik ettiği gerekçesiyle, kullanımının engellenmesi ve kullanımının para cezasına çarptırılmasına hükmetmiştir. Burada ilgili dayanak, bu 'oyuncağın' verdiği mesajın Alman Anayasasının temel prensibi olarak görülen insan onuruna aykırı bulunmasıdır. Eğlence amaçlı da olsa bu türden bir şiddetin ve insanı araç edinmenin ilgili prensibe aykırı olduğunu savunulmuştur. Dava, bir dizi idari temyiz mahkemesini aşarak Alman Federal Mahkemesinin önüne geldiğinde, Mahkeme, insan onuru prensibi ile aynı zamanda Birlik özelinde korunan başka 'haklar' olan mal ve hizmetlerin özgürlüğü ve malların serbest dolaşımı arasında nasıl bir denge kurması gerektiği konusunda Avrupa Adalet Divanı'ndan görüş istemiş ve insan onuru prensibini öncelemenin Avrupa Birliği Anlaşmasının 28 ve 49. maddeleriyle uyumlu olup olmayacağını sormuştur. Burada önemli olan sorulardan biri insan onurunun hukuki yorumunun ulusal bir marja sahip olup olamayacağı sorusudur; zira belirtildiği üzere kavram Alman Anayasas1 bakımından öncelikli ve özellikli bir yere sahiptir. Bir başka ifadeyle ülkelerin ulusal düzlemde insan onuru prensibini koruyup yorumlayabilmelerindeki sınır nedir? Bu dava bakımından bir başka soru: insan onurunun korunmasının, AB Sözleşmesi tarafından garanti altına alınmış olan Ortak Pazar'a bir çekince koymak açısından yeterli bir gerekçe olup olmayacağıdır. Avrupa Adalet Divanı, kararında, orantılılık ölçütü ile örtüştüğü sürece, temel bir hukuk değeri olan insan onurunun Ortak Pazar'a bir çekince

48 Brüstle v. Greenpeace, C-34/10 
koymak bakımından geçerli bir sebep olabileceğini kabul etmiştir. Daha da önemlisi Mahkeme, Birlik dâhilinde ortak bir onur tanımına dayanmanın zorunlu ve mümkün olmadığını ve dolayısıyla her tek ulusal düzlemde insan onuru, kamu yararı vb. kavramların farklı kültürel ve moral yorumları olabileceğini işaret etmiştir. Divan bu bakımdan bu ve benzer kavramların yorumuna ulusal bir marj tanımış ancak orantılık testi ve birlik hukukunun genel hatları ve amaçlarının yol gösterici olacağını belirtmiştir. ${ }^{49}$

AB İnsan Hakları Yargılamaları bakımından insan onurunun görünür olduğu konular aynı zamanda iltica ve geri gönderme prosedürleri ve bunların insancıl bir biçimde yürütülmesi konularıdır. Benzer biçimde yabancılara uygulanacak güvenlik politikaları, suçluların yakalanması ve iadesi, biyoetik konuları ve insan bedeni ve organlarının patentleştirilebilmesi davaları da insan onurunun bir argüman olarak belirdiği kategorilerdir. ${ }^{50}$

\section{INNSAN ONURU KAVRAMININ ARDINDA BIRAKTIĞI SORULAR VE BİR DEĞERLENDİRME}

Konunun yukarıda bırakıldığı noktadan hareketle söylenebilecek noktalardan ilki, kavramın giderek artan bir vurguyla insan hakları literatüründe yerini almaya devam ediyor olduğudur. Bu husus, gerek evrensel gerek de bölgesel insan hakları belgelerinde kavrama yapılan atıflarda gözlemlenmektedir. Ancak daha önce de belirtildiği üzere kavramla işaret edilebilecek haklar ve haksızlıklar bölgelerin ve daha özelinde ülkelerin, sosyo-kültürel arka planlarına göre değişim gösterebilecektir. Bu noktada önemli olan insan hakları fikri ve kültürü çerçevesinde elverişli olan yorum ve uygulamalara odaklanılmasıdır ancak literatürde konu Avrupa anayasacılığı ekseninde öne çıkar görünmektedir. Felsefi gerekçelendirmesi bir yana, kavramın bu belgeler 1şı̆̆ında en tartışmasız kullanımı insanlık ailesinin varlıkta sahip olduğu değerli bir alana işaret etmek ve insan haklarının hem varlık sebebini hem de amacını bu yeri korumak olarak

\footnotetext{
49 Supra 47.

50 Supra 45.
} 
görmek bakımındandır. Diğer yandan insan onurunun başlı başına bir insan hakkı olup olmadığı konusu, kavramı bilhassa ayrı bir madde ile düzenlemiş olan Avrupa Temel Haklar Şartı dışında muğlak görünmektedir.

Burada ele alınan sınırlı örnekler bakımından insan onurunun genellikle özgürlüklerin önünü açan ancak kimi zaman da onları sınırlayan bir kavram olduğu dile getirilebilir. Öte yandan insan hakları yargılamalarının, neliği bilinmeyen bir onura hizmet etmenin ötesinde neliği bilinen bir onuru korumak yönünde hizmet etmesi, şüphesiz daha anlamlı görünmektedir. Söz konusu 'ne'liğe ilişkin bir tartışma ise bu yazının ve salt bir hukuk dilinin sınırlarını aşmaktadır. Burada bir dipnot olarak söylenebilecek olan: insan onuruna toplumsal bir değer yargısı, kamusal ahlâk ya da düzen lehine atıfta bulunulan davalarda durumun içinden çıkılmasının karışık olduğu ve bu sorunun yargılamayı yapan devlet ve hukuk düzeninin neliği sorusundan bağımsız olmadığıdır. Bu da bize onur kavramının hukukla ilişkisinde salt hukuki bir kavram olarak değil aynı zamanda politik bir kavram olarak da rol oynadığını söyler. Bu bakımdan, insan onuruna yönelik bir atıfla, ne noktada yargılamayı yapan kişi ya da toplumun dayatmacı olabilecek değer yargılarının korunacağı, ne noktadaysa gerçekten insan onuru konu edinilen kişinin değerini korunduğu sorusu cevapsız kalabilmektedir. $\mathrm{Bu}$ anlamda evrensel ya da bölgesel yargılamalar çerçevesinde bu türden sorunlara daha az rastlanabildiği söylenebilir.

Görünen o ki yargılamalarda içkin bir onur anlayışına ve bu türden bir onurun zarar görüp görmemesine odaklanılması daha az risk taşımaktadır. Bu da kavramın en çok da insanın fiziksel ve psikolojik bütünlügüün hedef alan ve böylelikle somutlaşan kötü, insanlık dışı muamele ve işkence davalarında kullanılıyor olmasıyla desteklenir görünmektedir. Öte yandan, "onurlu bir hayat" fikrine konu olabilecek olan, içkin olmayan yani kazanılıp kaybedilebilecek türden toplumsal bir onur anlayışının da sosyo-ekonomik haklar bakımından önemli olduğunun altını çizmek önemlidir. Bu bakımdan kavramın sadece sivil hak ve özgürlükler bakımından negatif özgürlüklerle ilişki çerçevesinde değil de sözü edilen haklarla ilişkili “onurlu bir yaşam hakkına sahip olmak" bakımından da ele alınması önemlidir. Bu doğrultuda AB Temel Haklar Şartının 31. Maddesinde yer alan eşit ve adil çalışma hakkında yapılan insan onuru vurgusu, 
günümüzün egemen piyasa koşullarının yarattığı insan onurunun altına düşen yaşam biçimlerinin insan hakları ihlali olarak yargılanabilmesi için olası bir araç olarak görünmektedir. Yine görünen o ki Temel Haklar Şartı içkin bir insan onuru fikri ile en çok gerilim yaratabilecek olan teknolojik gelişmeler ve biyoetik konuların gündemine ve yargılamalarına alması bakımından görece önemli ve potansiyel vadeden bir noktada yer almaktadir.

\section{KAYNAKÇA}

BAGARIC, M\& ALLAN, J. "The Vacuous Concept of Dignity", Journal of Human Rights, Y11: 2006, Cilt: 5, Say1:2.

BARROSSO, Robert L., "Here, There, Everywhere: Human Dignity in Contemporary Law and in The Transnational Discourse", B.C. Int'l \& Comp. L. Rev, Y11: 2012, Cilt: 35, Say1: 2.

BAXI, Upendra, "The Place of Dignity in the Indian Constitution", içinde The Cambridge Handbook of Human Dignity (ed. Düwell) Cambridge University Press, 2014.

Bouyid v. Belgium, 23380/09

Brüstle v. Greenpeace, C-34/10

Christine Goodwin v. The United Kingdom 28957/95

CLAPHAM, Andrew, Human Rights Obligations of the Non State Actors, Oxford University Press, 2006.

CHASKALSON, Arthur, "Human Dignity as a Constitutional Value", The Concept of Human

Dignity in Human Rights Discourse (ed. D.K. Klein) Kluwer Law International, 2002.

DIXON R., NUSSBAUM M., “Abortion Dignity and a Capabilities Approach”, University of Chicago Public Law \& Legal Theory Working Paper No. 345, 2011. 
DONELLY, Jack, "Human Rights and Human Dignity: An Analytic Critique of Non-Western Conceptions of Human Rights", The American Political Science Review, Y11: 1982, Cilt: 76 .

DOUZINAS, Costas, Human Rights and Empire: The Political Philosophy of Cosmopolitanism Abingdon,Routledge-Cavendish Publishing, 2007.

Dudgeon v. United Kingdom 7525/76

DUPRE Catherine, The Age of Dignity: Human Rights and Constitutionalism in Europe, Hart Publishing, 2015.

HABERMAS, Jurgen, "The Concept of Human Dignity and The Realistic Utopia of Human Rights”, Metaphilosophy, Y11: 2010, Cilt:41, Sayı:4.

KANT, Immanuel, Ahlâk Metafiziğinin Temellendirilmesi (çev. İ. Kuçuradi), Türkiye Felsefe Kurumu Yayınları, 2009.

KLEIN, Eckart, The Concept Of Human Dignity in Human Rights Discourse (ed. D. Kretzmer) Kluwer Law International, 2002.

KOÇAK, Orhan, "İlişmeyelim: Haysiyet Kavramı Çerçevesinde", Defter Dergisi, Metis Yayınlar1, Y11: 2001, Sayı: 40.

KUÇURADİ, İoanna, İnsan Hakları Kavramı ve Sorunları, Türkiye Felsefe Kurumu Yayınları, 2007.

LIEBENBERG, Sandra, "The Value of Human Dignity in Interpreting Social and Economic Rights", 21 S. Afr. J. on Hum. Rts. 1, Y11: 2005.

MATSUI, Scigenori, "Human Dignity in Japanese Law", Cambridge Handbook on Human Dignity, 2014.

MCCRUDDEN, Cristopher, "Human Dignity and Judicial Interpretation of Human Rights", The European Journal of International Law, Y11: 2008, Cilt:19, Say1: 4.

MCCRUDDEN, Cristopher (ed.) Understanding Human Dignity, Oxford University Press, 2013. 
McDonald v. The United Kingdom 4241/12, 2014

LUCY, Michael, "Defining Dignity and its Place in Human Rights”, New Bioethics, Y1l: 2014, Cilt: 20, Sayı: 1

Mouisel v. France 67263/01, 2002

MOYN, Samuel, "The Secret History of Constitutional Dignity", Yale Human Rights and Development Journal, Y11: 2014, Cilt: 17, Say1: 1.

Omega Spielhallen- und Automatenaufstellungs-GmbH v Oberbürgermeisterin der Bundesstadt Bonn. C-36/02

Pretty v. The United Kingdom 2346/02, 2002

RAO, Neomi, "On the Use and Abuse of Dignity in Constitutional Law", Columbia Journal of European Law, Y11: 2008, Cilt: 14, Say1: 2.

Robert Faurisson v. France, Communication No. 550/1993 UN Doc CCPR/C/58/D/550/1993

R. v. Kapp, [2008] 2 S.C.R. 483, 2008 SCC 41

SCHROEDER, Doris, "Human Rights and Human Dignity", Ethical Theory and Moral Practice, Y11: 2012, Cilt: 15, Say1: 3.

SCHULTZINER, Doron, "Human Dignity: Functions and Meanings", Perspectives on Human Dignity: A Conversation (Malpas, Jeff, Lickiss, Norelle Ed.) 2007.

Siliadin v. France 73316/01

SNEAD, Carter, "Human Dignity in US Law" içinde Cambridge Handbook on Human Dignity (ed. Düwel) Cambridge University Press, 2014.

Svinarenko and Slyadnev v. Russia 32541/08 ve 43441/08

S.W v. UK (20166/92) A/355- B

TAYLOR, Charles, Multiculturalism Examining the Politics of Recognition, Princeton University Press, 1994. 
The Netherlands v. Eu Parliement and the Council Case C-377/98.

Villagran-Morales et al. v. Guatemala, 1999

Vo. v. France, 53924/00, 2004

WEISSTUB, David, "Honor Dignity and the Framing of Multicultural Values", The Concept of Human Dignity in Human Rights Discourse (ed. D.K. Klein) Kluwer Law International, 2002. 